\title{
MORPHOLOGY, BIOMETRICS AND GERMINATIVE POTENTIAL OF Mollinedia clavigera Tul.
}

\author{
Chaiane Rodrigues Schneider1*, Rodrigo Condé Alves ${ }^{1}$, Alexandre Dal Forno Mastella ${ }^{1}$, Mônica Moreno \\ Gabira $^{1}$, Letícia Siqueira Walter ${ }^{1}$, Antônio Carlos Nogueira ${ }^{2}$ \\ 1 * Federal University of Paraná, Postgraduate Program in Forest Engineering, Curitiba, PR, Brazil - (*chai.rodriguesschneider@ gmail.com; \\ rconde@gmail.com; alexandremastella@gmail.com; monica.gabira@gmail.com; leticiasiqueira.walter@gmail.com) \\ ${ }^{2}$ Federal University of Paraná, Department of Forest Sciences, Curitiba, PR, Brazil - (acnogueira.ufpr@gmail.com)
}

Received for publication: 12/12/2018 - Accepted for publication: 19/12/2019

\begin{abstract}
Resumo
Morfologia, biometria e potencial germinativo de Mollinedia clavigera Tul. A presente pesquisa objetivou avaliar a morfologia e biometria de frutos e sementes, bem como o potencial germinativo de sementes de Mollinedia clavigera Tul., da família Monimiaceae, espécie endêmica do Brasil. Foram identificadas suas estruturas internas e externas para avaliação da morfologia; para as características biométricas dos frutos e das sementes, considerou-se diâmetro e comprimento, além do peso e número de sementes por quilograma. A germinação foi avaliada sob diferentes condições de temperatura, de 20,25 e $30^{\circ} \mathrm{C}$, em dois substratos (papel e vermiculita). Para os resultados morfológicos, identificou-se características comuns para a família Monimiaceae, além da presença de larvas da família Curculionidae nas sementes. Os dados biométricos apresentaram valores médios de 7,42 $\mathrm{mm}$ de comprimento e 6,13 $\mathrm{mm}$ de diâmetro para os frutos, e 6,91 de comprimento e 5,07 $\mathrm{mm}$ de diâmetro para as sementes. Os resultados germinativos identificaram as temperaturas de 20 e $25^{\circ} \mathrm{C}$ como as mais propícias para emissão de radícula após 23 dias da instalação.

Palavras-chave: Germinação. Morfobiometria. Monimiaceae. Patógenos.
\end{abstract}

\begin{abstract}
This study aimed to evaluate the morphology and biometry of fruits and seeds, as well as germination potential of Mollinedia clavigera Tul. seeds, of the family Monimiaceae, an endemic species from Brazil. The internal and external structures have been identified for the evaluation of morphology. For biometric characteristics of fruits and seeds, we considered the diameter and length, plus the weight and number of seeds per kilogram. Germination was evaluated under the temperature of 20,25 and $30^{\circ} \mathrm{C}$ in two substrates (paper and vermiculite). As a morphological result, we identified common features to the Monimiaceae family, as well as the presence of Curculionidae larvae in the seeds. Biometric data showed mean values of $7.42 \mathrm{~mm}$ in length and $6.13 \mathrm{~mm}$ in diameter of fruits, $6.91 \mathrm{~mm}$ in length and $5.07 \mathrm{~mm}$ in diameter of seeds. Results have identified the temperatures of 20 and $25^{\circ} \mathrm{C}$ are the are the most suitable for germinaon, wich happend 23 days after experiment beginning.

Keywords: Mr. Germinaon. Mr. Morphobometry. Monimiaceae Pathogens.
\end{abstract}

\section{INTRODUCTION}

The historical paths that resulted in the development of the science of natural resources and, at the same time, the current resourcefulness of legislative policies to encourage the preservation of species, especially vegetables, with the restoration and preservation of the Legal Reserve and Riparian Forests, according to the requirements of the New Forest Code Federal Law No. 12,651/2012 (BRAZIL, 2012), showed that 12 million hectares of forests need to be restored, and the Brazilian government has committed to achieve this goal by 2030 (BRAZIL, 2016). Thus, it is expected an increase in the production of native tree species seedlings, however the productive reality of the tree seed sector in the country is not prepared to meet this demand, with limitations on the production scale, legal regularity of companies, financial incentives (FREIRE et al., 2017), production methodologies and determination of potential species.

These mishaps refer to the need for new alternatives in the production of seedlings of native species in Brazil, ensuring the genetic variability of seedlings inserted in these environments, in addition to the knowledge of the characteristics of the seeds of existing species in order to contribute, according to Haliski et al. (2013), both for its conservation and for its use. Among the attributes necessary for characterization, the morphology and biometrics of the fruit and seed, in addition to the germination potential that can be under different temperature or substrate conditions, are composed of information necessary for the production of seedlings.

In the morphological description of seeds and seedlings, the structures are differentiated, making it possible to obtain information on germination, in addition to an understanding of the functionality of these structures in ecosystems, evidencing the potential for ecological use in conservation, environmental restoration (COSMO et al., 2017; GOMES et al., 2015) and identification of the successional stage, (GOGOSZ et al., 2015) dispersion and regeneration.

Seed and fruit biometrics, in turn, is an information tool that allows the aggregation of these characteristics mentioned above. However, it occurs more intrinsically, with regard to the dynamics of dispersion and establishment, the genetic variability of the species within the population, the relationships between this variability and environmental factors (RICKLI-HORST et al., 2017), and the differentiation of species of the same genus (ZUFFO et al., 2016).

FLORESTA, Curitiba, PR, v. 50, n. 2, p. 1363 - 1372, abr/jun 2020

Schneider, C. R. et.al. 
In addition to the biometric aspects, another characteristic of interest is the germination potential. Germination consists of an important phase for the life cycle of plant species, which generally varies from species to species or from one lot to another and is evaluated from experiments in laboratories or nurseries (RICKLI-HORST et al., 2017). In these circumstances, the factors that influence it include the type of substrate used, the humidity, luminosity and temperature, providing the percentage of germinated seeds and the speed and uniformity that this occurs (COSMO et al., 2017). Germination, and the factors that interfere with it, support the propagation of native species, in addition to an understanding of natural regeneration in a community (COSMO et al., 2017), and the luminosity should also be considered due to the ecological characteristics of each species.

Despite the evident importance of this branch of science, as well as the studies that have been developed for the most varied species of interest, the knowledge gap on fruit morphology, seeds and seedlings focused on native forest species is still large (DE PAULA; WALNUT; ANGELO, 2016,). In this sense, investigative science has contributed to the understanding and dissolution of this problem, especially with regard to the behavior of species, notably shrubs and trees inserted in different forest typologies, in which the object of research of this study is part, the species Mollinedia clavigera Tul.

The genus Mollinedia Ruiz \& Pav consists of dioecious, rarely monoecious trees or shrubs. It is a neotropical genus, which covers approximately 50 species distributed in southern Mexico and throughout much of Brazils territory, also encompassing Paraguay and Bolivia. However, the greatest diversity of species is found in the Brazilian Atlantic Forest, with about 29 endemic species (LILY; PEIXOTO; PIGNAL, 2018). Among the endemic species, M. clavigera Tul., from the Monimiaceae Juss. family, popularly known as "Capixim-pimenteira", has confirmed occurrences in the South and Southeast states of Brazil.

The $M$. clavigera presents a very dense occurrence in the regenerative and understory strata of the forests in the secondary stage of succession, which includes the species in the group of early and late stages of secondary succession, with arboreal and shrubby life form, but mainly shrubby (MORO; MILAN; MORO, 2012). It is found at altitudes ranging from 250 to 1125 meters above sealevel in southern Brazil, especially in gallery forests, and in gentle slopes and underwoods of brazilian Mixed Ombrophilous Forests located between 700 and 800 meters (PEIXOTO, 2001).

Of course, for the development of seed quality standards, in addition to the production and insertion of the species in native forests, especially in areas in the restoration process for ecological enrichment, it is important to analyze the species in its early stages of development, since there are few related studies, the territorial scope of the species is great and the need to find potential species - due to future demand for land reclamation and forest restoration.

In view of these placements, the objective of this research was to evaluate biometrics, germination potential and morphology of fruits and seeds of Mollinedia.

\section{MATERIAL AND METHODS}

\section{Collection of fruits and seeds}

The fruits were collected from 13 shrub parent trees of $M$. clavigera selected in the forest fragment of approximately 15 hectares, popularly known as "Capão da Floresta" or, still, "Forest Trail". The area is located in Curitiba, State of Paraná, inserted in the Botanical Garden Campus of the Federal University of Paraná, under the geographical coordinates $25^{\circ} 26^{\prime} 54.40^{\prime \prime} \mathrm{S}$ and $49^{\circ} 14^{\prime} 25.28^{\prime \prime} \mathrm{W}$.

According to the Brazilian Institute of Geography and Statistics (IBGE, 2012), the metropolitan region of Curitiba is inserted in the Atlantic Rainforest biome, with the Mixed Ombrophilous Forest being the main forest typology found. According to the Köppen classification, the city has the climatic type $\mathrm{Cfb}$, with an altitude of $915 \mathrm{~m}$ above sea level, an average temperature of $17.1^{\circ} \mathrm{C}$, in which july comprises the coldest month, with an average of $13.0^{\circ} \mathrm{C}$, and january the warmest month, with an average of $20.7^{\circ} \mathrm{C}$. The average annual rainfall accumulated in the capital is 1,556 $\mathrm{mm}$, with august being the driest month, with an average of $71 \mathrm{~mm}$, and january the wettest month, with an average of 194 mm. (ALVARES et al., 2013).

The selection of parent trees was performed by walking on the trails existing in the forest fragment and proceeded to the collection of trees that had more intense fruiting, essentially close to the trails, always at a minimum distance of $20 \mathrm{~m}$ between trees, collecting the ripe fruits - which presented black coloration. The collections occurred between april 4 and may 2, 2018.

After collection, the fruits were sent to the Forest Seed Laboratory of the Department of Forest Sciences of the Federal University of Paraná for manual processing, which consisted of the removal of impurities and removal of the pericarp from the fruits with the aid of a strainer and running water. Subsequently, the seeds were dried at room temperature for 24 hours and then conducted in cold chamber storage until the organization of the experiments, which took about three weeks.

\section{Morphology}

In the morphological analysis of fruits and seeds, we used tweezers, cutting blades and biocular stereoscopic magnifying glass to identify the external and internal structures under observation of characteristics from cuts. The cuts made to visualize these structures were the longitudinal and transverse cut (in the third part of the seed), being unnecessary to submit the seeds to specific solutions for the activity. 
In the characterization of fruit morphology, the following aspects were evaluated: type, color, dimensions and consistency of the pericarp. The seeds, in turn, were evaluated for external and internal aspects. In the external ones, we considered the color, appearance of the endocarp surface, seed shape, hilum location, micropyle and seed raphe, length and diameter. From the internal structures, the cotyledons and embryonic axis (embryo components) and endosperm were identified.

Some germinated seeds were separated and observed during the development of the radicle until the emission of cotyledons. These were gathered for a photographic record of the seed and from the emission of the radicle until the exposure of the cotyledons.

\section{Biometrics, weight and humidity}

To obtain the biometrics of fruits and seeds, the measurements consisted of the length corresponding to the longest measurement, starting from the hilum to the opposite end, and the diameter corresponding to the thickest measure surrounding the seed or fruit.

Fruit biometrics were performed considering the seed and pericarp. In the case of seeds, biometrics were performed considering embryo, endosperm, tegument and endocarp. For this purpose, 50 units were measured for each measurement performed using a digital caliper considering two decimal places.

To estimate the weight of 1,000 seeds and quantity of seeds per kilogram, 16 replicates of 50 seeds and 8 replicates for the fruits were weighed on a precision scale (0.0001 g) (BRAZIL, 2009).

In obtaining the moisture content of seeds and fruits, three replicates of 50 seeds and two replications of 50 fruits were considered. Using the oven-drying method at $105 \pm 3{ }^{\circ} \mathrm{C}$ for 24 hours, the results were expressed as a percentage based on the wet weight of the seeds.

\section{Germination}

Before the installation of the germination test, the soaking curve was developed in order to evaluate the water absorption and the possibility of seed dormancy to later define the treatments used in germination. For the soaking curve, four replicates of 25 seeds each were used, arranged in Petri dishes, moistened with distilled water. The Petri dishes were packed in a BOD incubator with a constant temperature of $25^{\circ} \mathrm{C}$ and their weights measured until stabilization in the following time intervals: $0,3,6,9,12,24,36,48,60$ and 72 hours.

For the assembly of the germination test, the seeds were disinfected with $5 \%$ sodium hypochlorite solution for 5 minutes and then washed with distilled water, according to RAS methodology (BRAZIL, 2009). The seeds were placed on the substrates fine vermiculite $(20 \mathrm{~g})$ and blotter paper (two leaves) previously sterilized in an oven. Vermiculite was moistened with $60 \mathrm{ml}$ of distilled water, and the paper until saturation was then distributed in properly identified transparent plastic boxes (gerbox $\left.{ }^{\circledR}\right)$. In each repetition - gerbox ${ }^{\circledR}$ - 40 seeds were inserted.

The tests were conducted in seed germinators regulated for constant temperature regimes of $20{ }^{\circ} \mathrm{C}, 25{ }^{\circ} \mathrm{C}$ and $30{ }^{\circ} \mathrm{C}$, under illumination of fluorescent lamps connected 24 hours a day, inserted in an air-conditioned room at a temperature of $18{ }^{\circ} \mathrm{C}$, and the number of germinated seeds was evaluated daily, adopting as germination criterion the emission of radicle equal to or greater than $2 \mathrm{~mm}$.

\section{Analysis of the data}

For seed and fruit biometrics, the average, the standard deviation, coefficient of variation and amplitude were calculated, in addition to the weight of 1,000 seeds and number of seeds per kilogram.

In obtaining the moisture content (MC), the average percentage for fruits and seeds was calculated by the ratio of wet weight to dry weight. The germination speed index (GSI) was determined according to Maguire (1962); average germination time (AGT) according to Silva and Nakagawa (1995), with the result expressed in days after sowing.

$$
\mathrm{GU}=\frac{\mathrm{P}-\mathrm{p}}{\mathrm{P}-\mathrm{t}} \quad \mathrm{IVG}=\left(\frac{\mathrm{no} \mathrm{S}}{\mathrm{t}_{\mathrm{i}}}+\cdots+\frac{\mathrm{no} \mathrm{S}}{\mathrm{t}_{\mathrm{i}}}\right) \quad \mathrm{TMG}=\left(\frac{\mathrm{no} \mathrm{G}_{\mathrm{i}} * \mathrm{t}_{\mathrm{i}}+\mathrm{no} \mathrm{G}_{\mathrm{i}} * \mathrm{t}_{\mathrm{i}}}{\mathrm{no} \mathrm{G}_{\mathrm{i}}+\mathrm{n} \mathrm{G}_{\mathrm{i}}}\right)
$$

where: $\mathrm{P}=$ wet weight of the seed with total weight of the container, $\mathrm{w}=$ dry weight of the seed with total weight of the container, $\mathrm{t}=$ total weight of the container, $\mathrm{n}^{\mathrm{o}} \mathrm{S}=$ number of germinated seeds, $\mathrm{n}^{\circ} \mathrm{G}_{\mathrm{i}}=$ number of non-germinated seeds, $\mathrm{t}_{\mathrm{i}}=$ time in days.

The experiment was conducted in a completely randomized design, with the treatments distributed in a factorial arrangement $3 \times 2$ (three temperatures and two substrates), with five replications of forty seeds each.

After verifying its normality by Bartlett's test, the percentage and germination speed index data were submitted to variance analysis, and when there was significance, the averages were compared by the Tukey test at $5 \%$ probability $(\alpha=0.05)$. There was no need for data transformations, according to the tests of normality and homogeneity of variances.

\section{FINDINGS}

\section{Morphology}

The fruits (Figure 1) were classified as free multiple indeiscent head, black-nigrescent in the mature phase, with dimensions between $5-7 \mathrm{~mm}$ in diameter and 6-9 $\mathrm{mm}$ in length. In the seed processing, it was noticed that the 
endocarp has rigid consistency, being difficult to separate them from the seed episperm, which for this reason was considered part of the external structures of the seed.

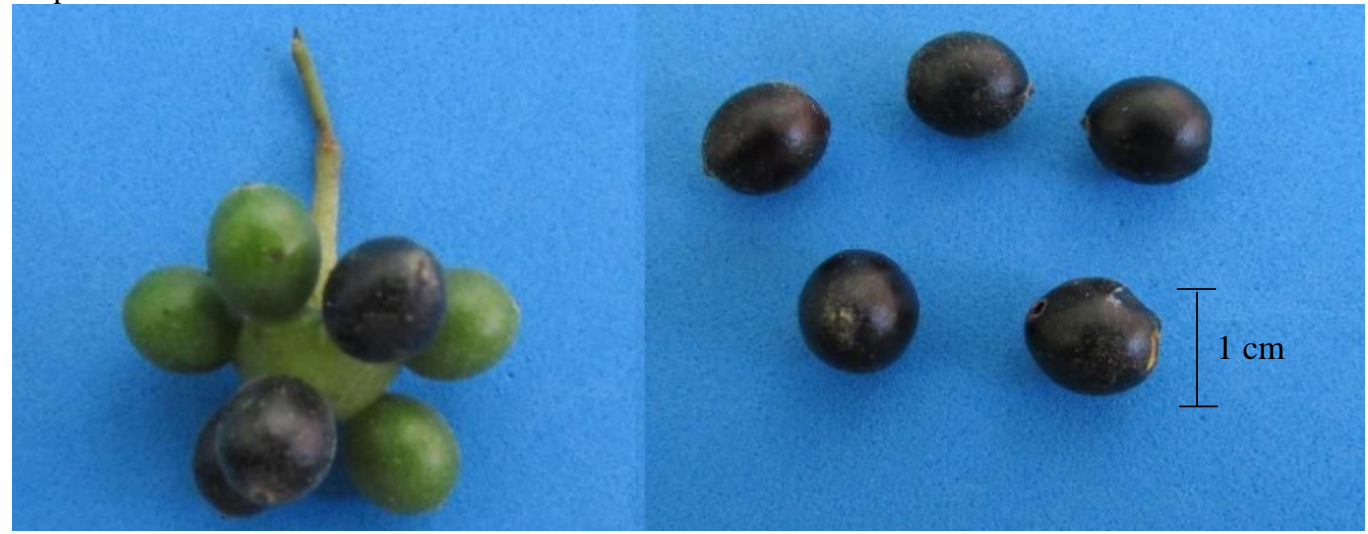

Figure 1. Fruits of the forest species Mollinedia clavigera Tul., collected in Curitiba - PR.

Figura 1. Frutos da espécie florestal Mollinedia clavigera Tul., coletados em Curitiba - PR

In the identification of the external structures (Figure 2A) of the seeds, the endocarp presents an opaque surface, of spotted color with a mixture of black and brown colors, dimensions of 4-6 $\mathrm{mm}$ in diameter and 5-9 mm length, ovalelliptical shape, with hilum and micropyle in the same arrangement, in addition to the absence of the seed raphe.

Among the internal structures of the seeds (Figure 2B), it was observed episperm of light brown color, with extremely thin thickness $(0.5 \mathrm{~mm})$, endosperm of transparent-white coloration and semicarnosal consistency occupying most of the seed (100\%), finding to be reserve endosperm. position.

The embryonic axis and the cotyledons (to a lesser extent) have yellowish-white coloration, located with axial

During seed processing, it was observed the presence of an insect larvae only confirmed in the seed germination process; in this study attributed as a pathogen of the species. The presence of this larva was confirmed in all seeds whose endocarp is marked by a scar that at tact presents roughness (Figure 3).

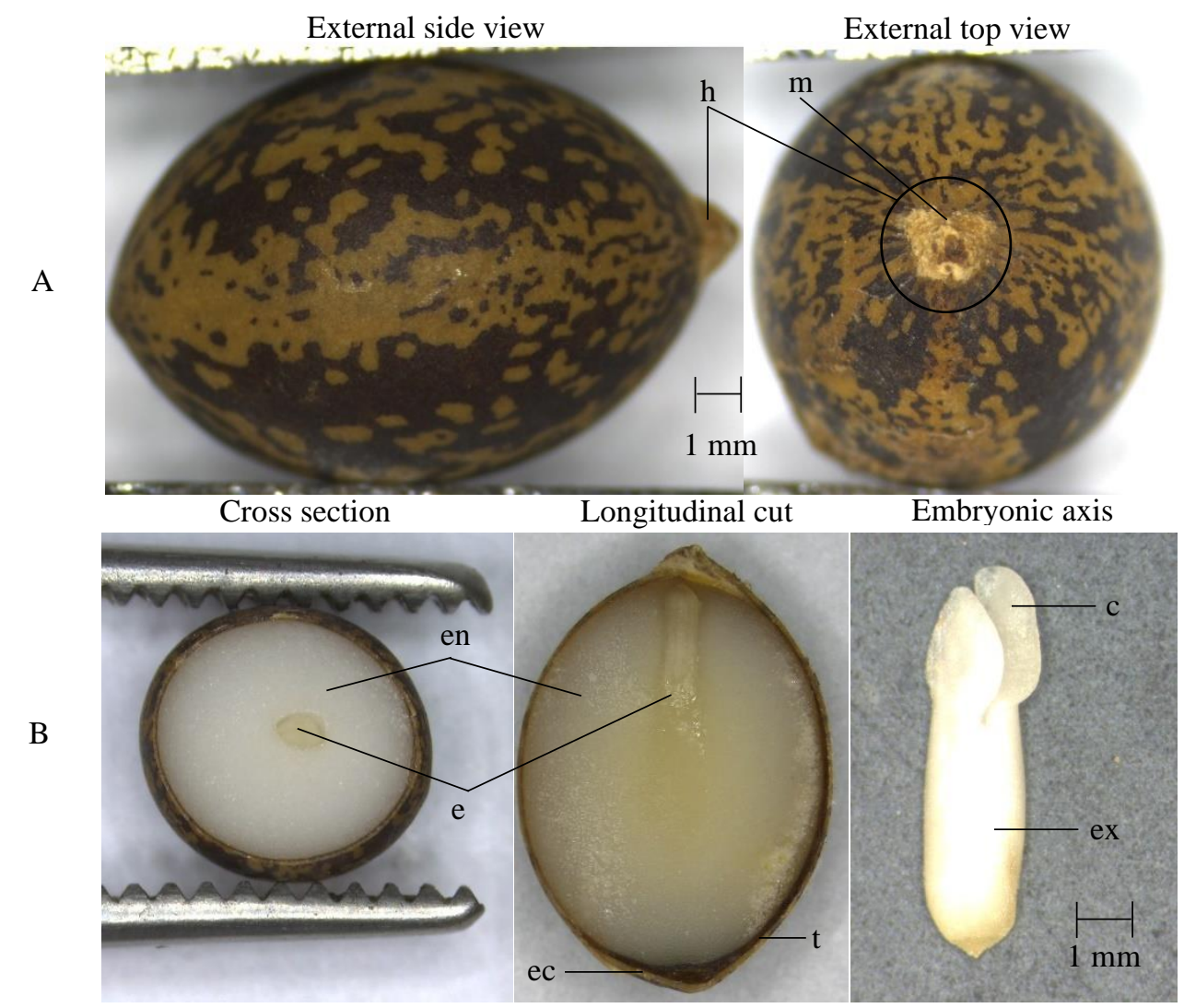

Figure 2. Characterization of the external (A) and internal (B) structures in the different perceptions and cuts of the seeds of Mollinedia clavigera Tul., hilo (h) and micropyle (m), endocarp (ec), tegument (t), endosperm (en), embryonic axis (ex), cotyledons (c) and embryo (e), in Curitiba - PR. 
Figura 2. Caracterização das estruturas externas (A) e internas (B), nas diferentes percepções e cortes, das sementes de Mollinedia clavigera Tul., hilo (h) e micrópila (m), endocarpo (ec), tegumento (t), endosperma (en), eixo embrionário (ex), cotilédones (c) e embrião (e), em Curitiba - PR.
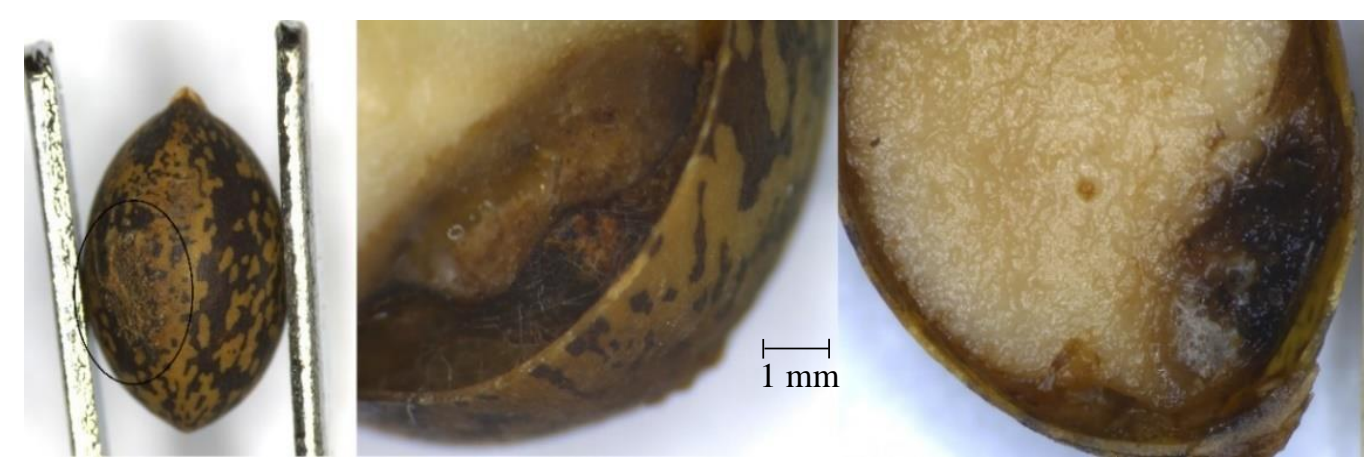

Figure 3. Scar and damages observed in the seeds of the species Mollinedia clavigera Tul., With the presence of larvae of the family Curculionidae, in Curitiba - PR.

Figura 3. Cicatriz e danos observados nas sementes da espécie Mollinedia clavigera Tul., com a presença de larvas da família Curculionidae, em Curitiba - PR.

After analysis, it was noticed that the larvae settle between the episperm and the endocarp and later invade the endosperm. The larvae were identified at the family level and belong to Curculionidae of the order Coleoptera. The larvae present yellowish-white coloration soon after hatching, which occurred mainly when still stored.

Another characteristic observed, both before the installation of the experiments and later, during the course of the tests, was the ease of proliferation of fungi that covered the seeds randomly in all the replications evaluated in the period, making them impossible to germinate. Even the hypochlorite solution did not prevent the development of fungi, which suggests a longer immersion time in the solution.

The seeds started the germination process with the emission of the radicle 23 days after the beginning of the experiment. It was observed that, close to this date, the seed began tobloat, indicating the absorption of water, staying in this state for a period of 3 days until pointing out the radicle. After 4 days, the radicle reached $2 \mathrm{~mm}$, size necessary to consider the effective germination of the seed. The growth of the radicle until the opening of the cotyledons occurred in the period of 8 weeks (Figure 4).

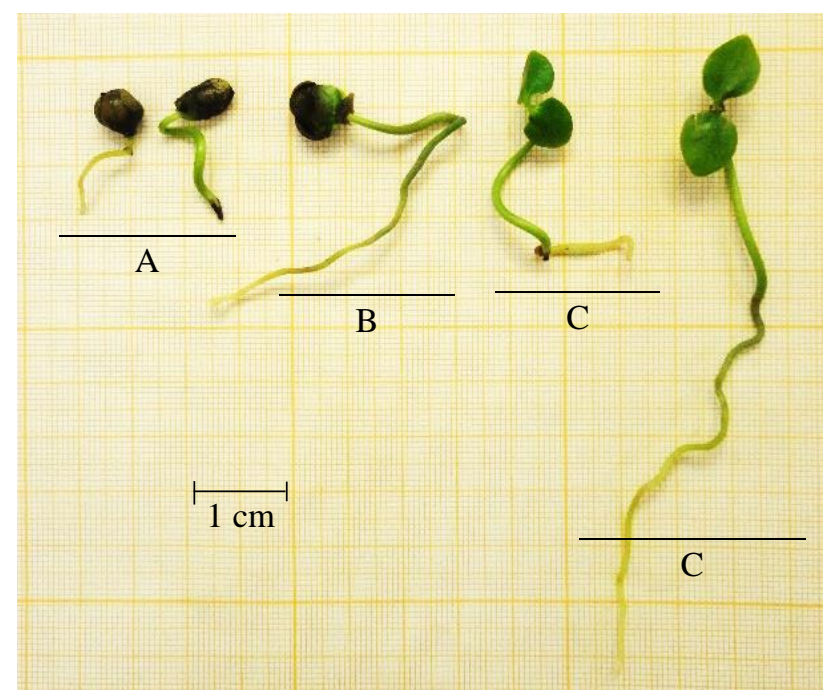

Figure 4. Stages of development: germination with radicle emission between 27 and 45 days (A); growth of the radicle up to 54 days (B) and emission of cotyledons between 60 and 70 days after germination (C) of seeds of the species Mollinedia clavigera Tul., in Curitiba - PR.

Figura 4. Estágios de desenvolvimento: germinação com emissão da radícula entre 27 e 45 dias (A); crescimento da radícula até 54 dias (B); e emissão dos cotilédones entre 60 e 70 dias após a germinação (C) de sementes da espécie Mollinedia clavigera Tul., em Curitiba - PR.

\section{Biometrics}

Fruit biometrics showed an average length of $7.42 \pm 0.50 \mathrm{~mm}$ and amplitude of $2.14 \mathrm{~mm}$, the average diameter was $6.13 \pm 0.32 \mathrm{~mm}$ with amplitude of $1.23 \mathrm{~mm}$. The average weight found for repetitions was $17.45 \pm 0.50 \mathrm{~g}$ with an

FLORESTA, Curitiba, PR, v. 50, n. 2, p. 1363 - 1372, abr/jun 2020. 
amplitude of $1.54 \mathrm{~g}$. In each kilogram of fruit there are on average 2,865.12 units and the average moisture content was $34.15 \%$ (Table 1).

Regarding seed biometrics, an average length of $6.91 \pm 0.66 \mathrm{~mm}$ with amplitude of $3.05 \mathrm{~mm}$ was found, and the average diameter was $5.07 \pm 0.36 \mathrm{~mm}$ with an amplitude of $1.77 \mathrm{~mm}$. The average weight found was $9.97 \pm 0.32 \mathrm{~g}$, with an amplitude of $1.13 \mathrm{~g}$. The weight of 1,000 seeds is 199.49 and the number of seeds per kilogram is approximately 5,013 . The seeds presented a moisture content of $51.62 \%$ (Table 1 ).

Table 1. Biometrics and resultant moisture content for fruits and seeds of Mollinedia clavigera Tul.

Tabela 1. Biometria e grau de umidade resultantes para os frutos e sementes de Mollinedia clavigera Tul.

\begin{tabular}{lccc|ccc}
\hline Biometrics & \multicolumn{3}{c|}{ Fruit } & \multicolumn{3}{c}{ Seed } \\
& $1(\mathrm{~mm})$ & $\mathrm{d}(\mathrm{mm})$ & $(\mathrm{w})$ & $1(\mathrm{~mm})$ & $\mathrm{d}(\mathrm{mm})$ & $(\mathrm{w})$ \\
\hline Minimum value & 6,41 & 5,49 & 18,39 & 5,75 & 4,2 & 9,35 \\
Average & 7,42 & 6,13 & 17,45 & 6,91 & 5,07 & 9,97 \\
Maximum value & 8,55 & 6,72 & 18,39 & 8,80 & 5,97 & 10,48 \\
Amplitude & 2,14 & 1,23 & 1,54 & 3,05 & 1,77 & 1,13 \\
$\mathrm{CV}(\%)$ & 6,74 & 5,25 & 2,87 & 9,56 & 7,18 & 3,25 \\
Standard deviation & 0,4998 & 0,3217 & 0,500 & 0,6604 & 0,3636 & 0,324 \\
\hline Average Deviation & 0,0707 & 0,0455 & - & 0,0934 & 0,0514 & - \\
$\mathrm{N}^{\circ} /$ Kg & 2.865 & & 5.013 & \\
Moisture content (\%) & \multicolumn{7}{c}{51,62} \\
\hline ficient of variation, l: length, d: diameter, w: weight, $\mathrm{N}^{\circ} / \mathrm{kg}:$ number of fruits or seeds per kilogram.
\end{tabular}

Key: CV: coefficient of variation, l: length, d: diameter, w: weight, $\mathrm{N}^{\circ} / \mathrm{kg}$ : number of fruits or seeds per kilogram.

\section{Germination}

Because it is a species lacking bibliographic records regarding its structures, germination potential and dormancy, the soaking test was performed to verify the permeability or impermeability of the endocarp and episperm. The results obtained can be seen in Figure 5, in which the seeds presented higher water absorption in the first nine hours, tending to stabilize later.

The stabilization of the curve started 36 hours after the beginning of the test, which indicates the absence of episperm impermeability of the seed, thus, the germination test was performed without any dormancy breaking methodology.

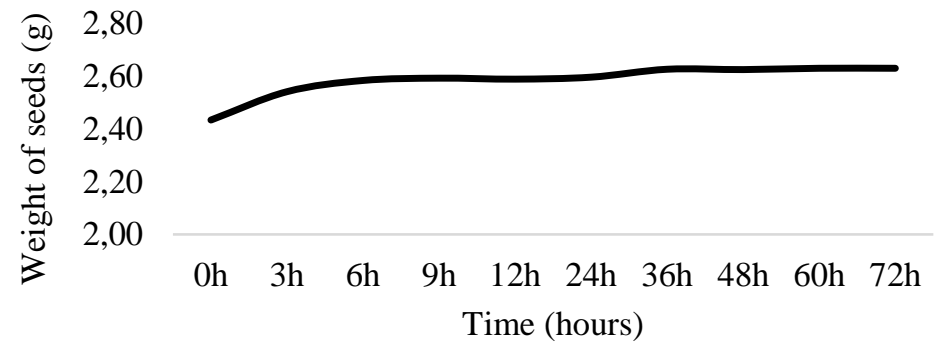

Figure 5. Soaking curve of Mollinedia clavigera Tul. seeds, in Curitiba - PR.

Figura 5. Curva de embebição das sementes de Mollinedia clavigera Tul., em Curitiba - PR.

About the average germination percentage results $(\mathrm{G} \%)$ (Table 2), there was no significant interaction $(\mathrm{P}>0.05)$ between substrate and temperature for any of the variables evaluated, thus, the effects of the factors studied for germination percentage proved to be independent. It is observed that the vermiculite substrate is superior and differs statistically from the paper at all temperatures. The temperatures of 20 and $25{ }^{\circ} \mathrm{C}$ show the best results, not differing from each other and being statistically higher than the temperature of $30{ }^{\circ} \mathrm{C}$.

Similarly, among the treatments evaluated, the percentage of non-germinated seeds for the total seeds tested reached $66.83 \%$ on paper and $52.17 \%$ for vermiculite substrate, considering all temperatures. Possibly the presence of fungi caused the high rate of non-germinated seeds. The percentage of non-germinated seeds at each temperature for each substrate, presented in Table 2, shows lower germination potential for the temperature of $30{ }^{\circ} \mathrm{C}$ in both substrates.

Regarding the germination speed index (GSI) (Table 2), vermiculite at temperatures of 20 or $25^{\circ} \mathrm{C}$ was higher than the paper, with no statistical difference between temperatures that, however, differed from $30{ }^{\circ} \mathrm{C}$, in which no significant differences were also observed between the substrates tested. However, the average germination time (AGT) did not present statistically significant differences in the temperatures evaluated, nor in the substrates tested. Germination started on the 23rd day after the installation of the experiment and it lasted a total of 57 days, being interrupted when there was no germination for 4 consecutive days (Figure 6)

Table 2. Results obtained in treatments for germination percentage (G \%), germination speed index (IVG) and average germination time (TMG) and percentage of non-germinated seeds of Mollinedia clavigera Tul., in Curitiba $-\mathrm{PR}$.

FLORESTA, Curitiba, PR, v. 50, n. 2, p. 1363 - 1372, abr/jun 2020 Schneider, C. R. et.al 
Tabela 2. Resultados obtidos nos tratamentos, para percentagem de germinação (G\%), índice de velocidade de germinação (IVG) e tempo médio de germinação (TMG), e percentagem de sementes não germinadas de Mollinedia clavigera Tul., em Curitiba - PR.

\begin{tabular}{|c|c|c|c|c|}
\hline \multirow{2}{*}{ Germination Information } & \multirow{2}{*}{ Substratum } & \multicolumn{3}{|c|}{ Temperature } \\
\hline & & $20{ }^{\circ} \mathrm{C}$ & $25^{\circ} \mathrm{C}$ & $30^{\circ} \mathrm{C}$ \\
\hline \multirow{2}{*}{ Germination percentage } & $\mathrm{V}$ & 64,50 aA & 58,50 aA & $20,50 \mathrm{aB}$ \\
\hline & $\mathrm{P}$ & 48,50 bA & 43,50 bA & $7,50 \mathrm{bB}$ \\
\hline \multirow{2}{*}{ Germination speed index } & $\mathrm{V}$ & 0,7510 aA & 0,6307 aA & $0,1881 \mathrm{aB}$ \\
\hline & $\mathrm{P}$ & 0,5145 bA & 0,4233 bA & $0,06940 \quad \mathrm{aB}$ \\
\hline \multirow{2}{*}{ Average germination time } & $\mathrm{V}$ & 35,5007 aA & 38,5172 aA & 44,5444 aA \\
\hline & $\mathrm{P}$ & 38,6072 aA & 41,8819 aA & 34,9583 aA \\
\hline \multirow{2}{*}{ Percentage of non-germinated seeds $(\%)$} & $\mathrm{V}$ & 35,50 & 41,50 & 79,50 \\
\hline & $\mathrm{P}$ & 51,50 & 56,50 & 92,50 \\
\hline
\end{tabular}

Key: V: vermiculite, P: paper, averages followed for the same very small letter in the vertical line and capital letter in the horizontal line do not differ for Tukey test $\alpha=0,05$.

A
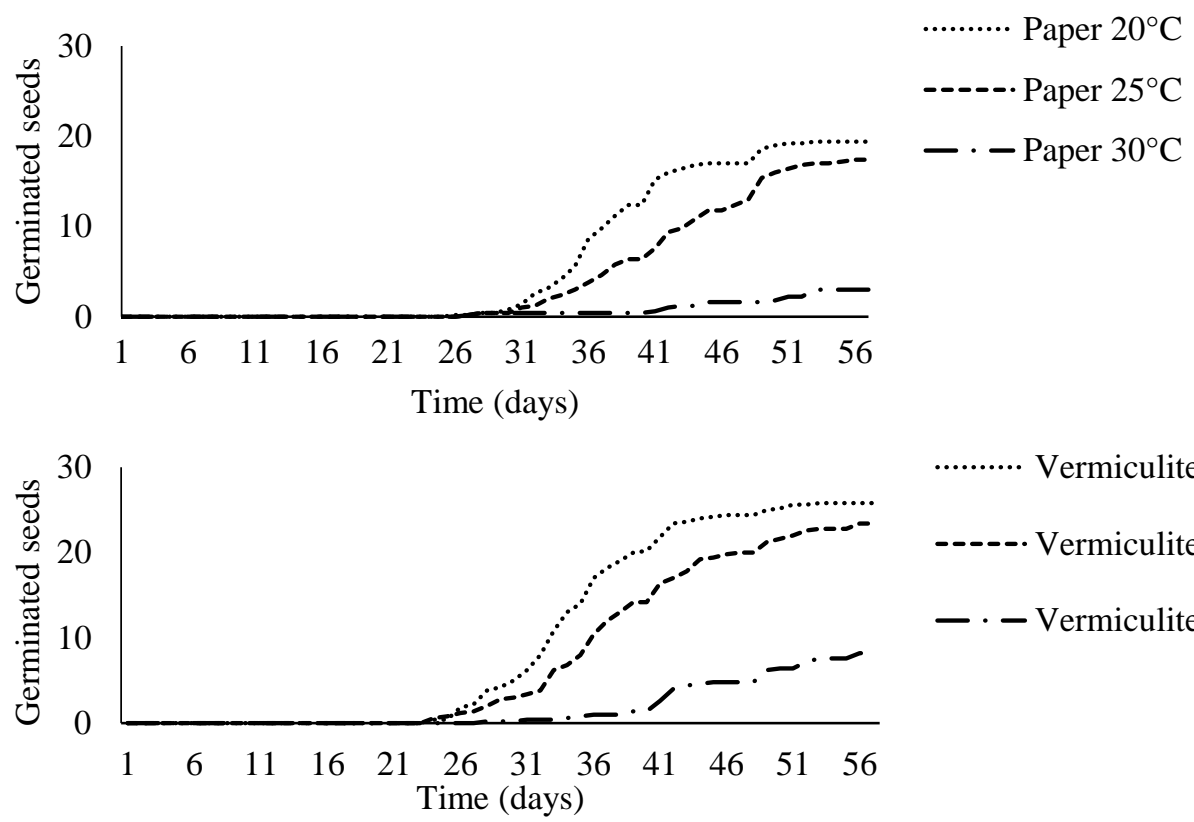

............ Vermiculite $20^{\circ} \mathrm{C}$

-.... Vermiculite $25^{\circ} \mathrm{C}$

$-\cdots$ Vermiculite $30^{\circ} \mathrm{C}$

$\mathrm{B}$

Time (days)

Figure 6. Accumulated germination curve (G\%) of Mollinedia clavigera Tul. seeds in the paper (A) and vermiculite (B) substrates in Curitiba - PR.

Figura 6. Curva acumulada de germinação (G\%) das sementes de Mollinedia clavigera Tul., nos substratos papel (A) e vermiculita (B) em Curitiba - PR.

\section{DISCUSSION}

\section{Morphology}

In general, the identified characteristics are similar to the observed ones in other studies on the Monimiaceae family, or the genus Mollinedia (PEIXOTO, 2002; PEIXOTO, 2001; BARROSO et al., 1999). On the external structures observed for fruits and seeds of the species M. clavigera, the hilum and micropyle are arranged at the base of the seed at one end, the hilum being considered ventral, followed by the micropyle represented by a small hole imperceptible to the naked eye (BARROSO et al., 1999).

The presence of rigid endocarp added to the episperm (GOGOSZ et al., 2015) possibly favors the germination delay of the seeds of Mollinedia, since the endocarp assumes additional characteristics of the episperm, of seed protection. According to Barroso et al. (1999), seeds do not always present a very distinct testa and episperm, and sometimes at maturity the episperms are confused into one and the structure and consistency of the episperms vary according to the type of fruit that encloses the seed.

Cotyledons are well differentiated, oval in shape, as described by Barroso et al. (1999), and possibly exert haustorial function within the seed, that is, at the beginning of the germination process, they carry out the transport of food reserves, a characteristic of most late secondary species, in which cotyledons remain for a long period trapped inside the seed (GOGOSZ et al., 2015). 
As for the occurrence of the larvae, it was observed that it was higher over time, but in a short period, due to the hatching of many larvae in only 24 hours. To hatch, the larvae require moisture, a condition offered by the high moisture of the seed when compared to the fruit in which it favored the hatching of the larvae after the removal of the existing rigid pericarp.

The larvae of the order of the Coleoptera are of the Curculioniform type, of the family Curculionidae, the most numerous of the animal kingdom. Classified as phytophagous, that is, it feeds on plant materials, the characterization of the family demonstrates that most species have endophytic posture (GALLO et al., 2002). This description evidences the possible posture in reproductive tissues when the fruit was still in formation, since no holes or perforations were observed in the ripe fruits both with the naked eye and in a stereoscopic magnifying glass.

By considering these characteristics in the field, we can subsidize the beneficial idea of insertion of this species in forest restoration projects. The fruits can serve as food to the fauna, while, in contact with the soil, will easily degrade or germinate. With the hatching of larvae, in addition to fruits, small insects and larvae serve as food, essentially for the avifauna. Thus, it is inferred about the dispersal syndrome of the species, which is characterized as zoochoric (GOGOSZ et al., 2015; SOUTO, SOUTO; BOEGER, 2011).

\section{Biometrics and moisture content}

According to the averages obtained, the observed form of fruits and seeds is similar to the dimensions described by Peixoto (2001) in which the drupes are between 0.9 to $1.2 \mathrm{~cm}$ long and 0.6 to $1.0 \mathrm{~cm}$ wide. Thus, surely the shape of the fruits and seeds are characterized from oval to elliptical, also confirmed by the average values of diameter and the highest coefficient of variation identified for the length. The greater variation of the values for the length of fruits and seeds evidences the greater distribution of the values with less frequency of the data.

It is evident that the length varies more from one seed to another and that both the fruit and the seeds do not seem to be influenced by the conditions of the environment with regard to weight and diameter, but by the characteristics of the species. The length, however, is possibly influenced by these conditions, which does not prevent or hinder the identification of fruits in the field. Similarly, when comparing the biometrics of fruits and seeds, it is noted that the coefficient of variation is higher for the seeds than for the fruits, due to the fact of morphological protection, from fruit to seed, which evidences the lower influence that the fruits suffer from the environment in relation to the seeds.

As mentioned earlier, the processing showed resistance of fruit removal. This resistance, in turn, protects the seed from the environmental conditions that, by the results, indicate influencing their dimensions. However, the fruit of this species did not exercise protection of the seeds against larvae, since many seeds presented larvae that hatched and derailed germination.

The weight of fruits and seeds did not vary much, ensuring the number of seeds or fruits per kilogram, which expresses approximately twice as many seeds in the absence of fruits.

The moisture content of the seeds obtained was higher than for the fruits. This fact can be explained by the thickness that the pericarp presents, that is, the thickness of the pericarp because it is much lower than the volume of the seed that occupies most of the fruit, resulting in this difference in the percentage of moisture content.

In addition, the higher degree of moisture in the seeds justifies the ease of fungal proliferation that occurred in the germination process, in which further studies should address the best way to conduct germination in addition to paying attention to the storage of seeds of M. clavigera.

\section{Germination}

The soaking curve that demonstrated water absorption, evident in the first nine hours, reflects in a episperm characteristic of permeability. Despite these characteristics, the seed does not present rapid germination speed, possibly justified by the presence of the endocarp, in addition to susceptibility to fungi and the presence of larva of the family Curculionidae. The germination speed index (GSI), higher at $20^{\circ} \mathrm{C}$, and the highest number of seeds germinated in the vermiculite substrate, for 20 and $25^{\circ} \mathrm{C}$, express the characteristics of the species when inserted in the forest environment. When considering these germination results, concomitantly the characteristics of the parent trees in which the seeds were collected, an ecological behavior of a species belonging to initial and late succession stages is evidenced, a characteristic also described by Gogosz et al. (2015).

The location of the parent trees near the trails, evidences the conditions of temperature, substrate and luminosity necessary for germination and development of the species. According to Peixoto (2001); Avila et al. (2013), the species of the Monimiaceae family adapt to environments with diffuse light and do not present pronounced requirements regarding edaphic conditions, which favors their wide distribution and abundance in the understory. In this sense, $M$. clavigera can occur quite densely in the regenerative stratum of secondary succession areas.

This fact is still confirmed by observing the germination test of this study, at a temperature of $30{ }^{\circ} \mathrm{C}$, which presented the lowest number of seeds germinated for both vermiculite and paper, being an unsatisfactory result. In another study to verify the biodiversity of the herbaceous-shrub stratum in capons in the Vila Velha State Park, it was found that the species $M$. clavigera is associated with the shrubby stratum of more biodiverse fragments, assuming that the plant has great ecological importance due to the significant occurrence in the understory of the Mixed Ombrophilous Forest. Thus, it can be an interesting species in the process of natural regeneration among secondary species, since it develops in gradients with lower temperature variations, preferring small openings (natural gaps) inside the forest (MORO; MILAN; MORO, 2012). 
These characteristics added to the results of the average germination time (AGT), which did not present statistically significant differences between the substrates and temperatures evaluated, express that the seeds do not have germination homogeneity. Moreover, in general, it can be observed that germination is directly influenced by morphological and biometric characteristics in addition to susceptibility to pathogens, which resulted in a high percentage of non-germinated seeds.

\section{CONCLUSIONS}

- The fruits and seeds of Mollinedia clavigera Tul. present common morphological characteristics of the monimiaceae family, and biometric characteristics show low variability except for length.

- The germination percentage is low and uneven, starting between 23 and 46 days. It is recommended to use vermiculite substrate at temperatures between 20 and $25^{\circ} \mathrm{C}$ to germinate M. clavigera. Additionally, the species can presents beetle larvae in its structures that must be observed before conducting germination.

- Among the observed characteristics, it can be concluded that for the use of the species it is necessary to consider its susceptibility to pathogens and the ecological characteristics of successional stage.

\section{REFERENCES}

ALVARES, C. A.; STAPE, J. L.; SENTElHAS, P. C.; GONÇALVES, J. L. M.; SPAROVEK, G. Köppen's climate classification map for Brazil. Meteorologische Zeitschrift, v. 22, n. 6, p. 711 - 728, 2013.

AVILA, A. L.; ARAUJO, M. M.; GASPARIN, E.; LONGHI, S. J. Mecanismos de regeneração natural em remanescente de Floresta Ombrófila Mista, RS, Brasil. Cerne, Lavras, v. 19, n. 4, p. 621 - 628, 2013.

BARROSO, G. M.; MORIM, M. P.; PEIXOTO, A. L.; ICHASO, C. L. F. Frutos e sementes: morfologia aplicada à sistemática de dicotiledôneas. Viçosa: UFV, 1999. 443 p.

BRASIL. 2016. Informação adicional sobre a iNDC apenas para fins de esclarecimento. Disponível em: <http://www.itamaraty.gov.br/images/ed_desenvsust/BRASIL-iNDC-portugues.pdf>. Acesso em: 26 ago. 2018.

BRASIL. Lei $n^{\circ}$ 12.651, de 25 de maio de 2012. Dispõe sobre a proteção da vegetação nativa; altera as Leis nos 6.938, de 31 de agosto de 1981, 9.393, de 19 de dezembro de 1996, e 11.428, de 22 de dezembro de 2006; revoga as Leis nos 4.771, de 15 de setembro de 1965, e 7.754, de 14 de abril de 1989, e a Medida Provisória no 2.166-67, de 24 de agosto de 2001; e dá outras providências. Diário Oficial da União, Brasília, DF, vinte cinco de maio de 2012. Disponível em: <http://www.planalto.gov.br/ccivil_03/_Ato2011-2014/2012/Lei/L12651.htm>. Acesso em: ago. 2018.

BRASIL. Ministério da Agricultura, Pecuária e Abastecimento. Regras para análise de sementes. Ministério da Agricultura, Pecuária e Abastecimento. Secretaria de Defesa Agropecuária. - Brasília: Mapa/ACS, 2009. 399 p.

COSMO, N. L.; GOGOSZ, A. M.; REGO, S. S.; NOGUEIRA, A. C.; KUNIYOSHI, Y. S. Morfologia de fruto, semente e plântula, e germinação de sementes de Myrceugenia euosma (O. Berg.) D. Legrand (Myrtaceae). Floresta, Curitiba, PR, v. 47, n. 4, p. 479 - 488, 2017.

DE PAUlA, S. R. P.; NOGUEIRA, A. C.; ANGELO, A. C. Caracterização morfológica do fruto, semente, fases da germinação e plântula de Ocotea paranaenses. Revista de Ciências Agroveterinárias, Lages, v. 15, n. 2, p. 103 - 108 , 2016.

FREIRE, J. M.; URZEDO, D. I.; PINA-RODRIGUES, F. C. M. A realidade das sementes nativas no Brasil: Desafios e oportunidades para a produção em larga escala. Seed News: Pelotas, RS, p. 24 - 28, 2017. Disponível em: <https://www.researchgate.net/publication/322581933/download>. Acesso em: 26 ago. 2018.

GALlO, D.; NAKANO, O.; CARVALHO, R. P. L.; BAPTISTA, G. C. De; BERTI FILHO, E.; PARRA, J. R. P.; ZUCCHI, R. A.; ALVES, S. B.; VENDRAMIM, J. D.; MARCHINI, L. C.; LOPES, J. R. S.; OMOTO, C. Entomologia Agrícola. Piracicaba: FEALQ, 2002. 920 p.

GOGOSZ, A. M.; BOEGER, M. R. T.; COSMO, N. L.; NOGUEIRA, A. C. Morfologia de diásporos e plântulas de espécies arbóreas da floresta com Araucária, no sul do Brasil. Floresta, Curitiba, PR, v. 45, n. 4, p. 819 - 832, 2015.

GOMES, J. P.; OLIVEIRA, L. M.; FRANÇA, C. S. S.; DACOREGIO, H. M.; BORTOLUZZI, R. L. C. Caracterização morfológica de plântulas durante a germinação de sementes de Psidium catteilanum e Acca sellowiana (Myrtaceae). Ciência Florestal, Santa Maria, v. 25, n. 4, p. 1035 - 1042, 2015.

HALISKI, S.; COSMO, N. L.; GOGOSZ, A. M.; REGO, S. S.; NOGUEIRA, A. C.; KUNIYOSHI, Y. S. Caracterização mosrfológica de frutos, sementes, plântulas e germinação de sementes de Casearia decandra. Pesq. flor. bras., Colombo, v. 33, n. 75, p. $253-259,2013$. 
INSTITUTO BRASILEIRO DE GEOGRAFIA E ESTATÍSTICA (IBGE). Manual técnico da vegetação brasileira. Departamento de Recursos Naturais e Estudos Ambientais. 2 ed. Rio de Janeiro: IBGE, 2012. 271 p.

LÍRIO, E. J.; PEIXOTO, A. L.; PIGNAL, M. Monimiaceae in Flora do Brasil 2020 em construção. Jardim Botânico do Rio de Janeiro. Disponível em: <http://reflora.jbrj.gov.br/reflora/floradobrasil/FB10070>. Acesso em: 01 ago. 2018.

MAGUIRE, J. D. Speed of germination-aid in selection and evaluation for seedlings emergence and vigor. Crop Science, v. 2, n. 1, p. 176 - 177, 1962. Disponível em: 〈https://eurekamag.com/pdf/014/014195562.pdf〉. Acesso em: 01 ago. 2018.

MORO, R. S.; MILAN, E.; MORO, R. F. Biodiversidade do estrato herbáceo-arbustivo em capões no Parque Estadual de Vila Velha, Ponta Grossa, PR. Biodiversidade Brasileira, Brasília: DF, v. 2, n. 2, p. 102 - 112, 2012. Disponível em: <http://www.icmbio.gov.br/revistaeletronica/index.php/BioBR/article/view/278/218>. Acesso em: 15 jul. 2018.

PEIXOTO, A. L. Monimiaceae. Parte integrante da Flora Fanerogâmica do Estado de São Paulo. In: Wanderley, M. G. L., Shepherd, G. J., Giulietti, A. M., Melhem, T. S., Bittrich, V., Kameyama, C. (eds.) Flora Fanerogâmica do Estado de São Paulo. Instituto de Botânica, São Paulo, vol. 2, p. 189 - 208, 2002 . Disponível em: <http://botanica.sp.gov.br/files/2016/02/Monimiaceae.pdf>. Acesso em: 01 set. 2018.

Monimiáceas. Flora Ilustrada Catarinense. Herbário Barbosa Rodrigues - HBR. Itajaí, SC. 64 p. 2001.

RICKLI-HORST, H. C.; DUARTE, M. M.; CHIRINZANE, C. J.; NOGUEIRA, A. C. Carposeminal biometry and germination of Cabralea canjerana (Vell.) Mart. Floresta, Curitiba, PR, v. 47, n. 4, p. 391 - 396, 2017.

SILVA, J. B.; NAKAGAWA, J. Estudos de fórmulas para cálculo de velocidade de germinação. Informativo ABRATES, v. 5 , n. 1, p. 62 - 73, 1995.

SOUTO, M. A. G.; BOEGER, M. R. T. Estrutura e composição do estrato de regeneração e vegetação associada de diferentes estádios sucessionais no leste do Paraná. Ciência Florestal, Santa Maria, v. 21, n. 3, p. 393 - 406, 2011.

ZUFFO, A. M.; GESTEIRA, G. S.; ZUFFO JUNIOR, J. M.; ANDRADE, F. R.; SOARES, I. O.; ZAMBIAZZI, E. V.; GUILHERME, S. R.; SANTOS, A. S. dos. Caracterização biométrica de frutos e sementes de mirindida (Buchenavia tomentosa Eichler) e de inajá (Attalea maripa (Aubl.) Mart.) na região sul do Piauí, Brasil. Revista de Ciências Agrárias, v. 39, n. 3, p. 331 - 340, 2016. 